\title{
Educational Pathway and Social Mobility in Children of Immigrants
}

\author{
Michael Dunn ${ }^{1}$ \\ ${ }^{1}$ Department of Management and Business, Skidmore College, Saratoga Springs, NY, USA \\ Correspondence: Michael Dunn, Department of Management and Business, Skidmore College, 815 North \\ Broadway, Saratoga Springs, NY 12866, USA. Tel: 1-518-580-5152. E-mail: mdunn@skidmore.edu
}

Received: June 9, 2019

Accepted: July 13, 2019

Online Published: November 29, 2019

doi:10.5539/ies.v12n12p44

URL: https://doi.org/10.5539/ies.v12n12p44

\begin{abstract}
This paper looks at degree completion and wages of immigrants to understand the extent to which a student's chosen educational pathway limits his or her social mobility. Statistical modeling established the predictive strengths of key variables on educational pathway and statistical analysis is used to understand the relationship between educational pathway, degree completion, and wages. Findings show that educational pathway mediates many of the background determinants that previous research identified as key mechanisms for immigrant social mobility. Furthermore, findings also identify a significant "pathway wage penalty" despite degree completion. New immigration plus births to immigrants added more than 22 million people to the U.S. population in the last decade, equal to 80 percent of total population growth. Immigrants and their children now account for more than one in five public school students. The impact of immigrants and their children on the US population, and the education system, underscores the importance of research examining the immigrant experience.
\end{abstract}

Keywords: education, degree completion, wages, children of immigrants, social mobility, community college

\section{Introduction}

It is well documented that educational attainment can have a significant impact on social mobility (Haveman \& Smeeding, 2006; Torche, 2011; Breen, 2019). Studies have also shown that children of immigrant tend to outperform their native-born peers despite disadvantaged backgrounds (Tran, 2018; also see historical review by Buriel, 2012) This paper demonstrates that educational pathway, the initial point of entry into the higher education system, when considered, mediates many of the background determinants that previous studies have identifies as key mechanisms for social mobility. It shows that when education pathways are considered children of immigrants show similar behavior of their native-born peers.

Using the Children of Immigrants Longitudinal Study (CILS), this paper examines the educational pathways of children of immigrants. It looks at degree completion and wages to understand the extent to which a student's chosen educational pathway limits his or her social mobility. It examines student outcomes post-high school by following students who enter directly into four-year institutions, students who enter the vocational/community college system, and students who did not immediately enter the higher education system. Previous research has focused on educational attainment without delineating by educational pathway. The current study advances the literature by including vocational/community colleges within the context of the higher education system, while simultaneously differentiating between educational pathways. This approach furthers our understanding of the impact that educational pathway has on degree completion and wages. Findings also identify a significant pathway-driven wage penalty, despite degree completion.

\section{Literature Review}

\subsection{Education, Immigrants, and Social Mobility}

The body of literature examining immigrants, their social and economic outcomes, and the role of education is firmly rooted in both the migration and education literatures. Scholars have shown the importance of peer influences (Portes \& Zhou, 1993), communities and neighborhoods (Zhou \& Bankston, 1998; Pong \& Hao, 2007), and modes of incorporation (e.g., Kao \& Tienda, 1995; Hao \& Bonstead-Bruns, 1998) on immigrant mobility. Research has also shown that over time, compared to historical trends, newer immigrants to the United States are incorporating more quickly than previous immigrants, and the educational and income gaps between immigrants and native-born whites have narrowed significantly (Pearlman \& Waldinger, 1997; Smith, 2003; Solon, 2018). Additionally, many have focused on the immigrant cultural emphasis on hard work and education achievement as 
a driving force for the success (Kao \& Tienda, 1993; Hao \& Bonstead-Bruns, 1998; Goyette \& Xie, 1999; Hsin \& Xie, 2014; Feliciano \& Lanuza, 2016).

\subsection{Assimilation and Social Mobility}

Level of incorporation has long been used as a predictor of social mobility (Portes \& Zhou, 1993; Reitz, 2018). Portes and Zhou (1993) assert three possible paths of (segmented) assimilation. The first is essentially what is predicted by classical assimilation theory: integration into the American middle class, which constitutes - and leads to further - upward mobility. The second path is assimilation into the urban underclass, leading to poverty and downward mobility. Lastly is "selective acculturation" (Portes \& Rumbaut, 2001, p. 54), which is the deliberate preservation of the immigrant community's culture and values, accompanied by economic integration; this pathway results in upward mobility (Portes \& Zhou, 1993). As a key predictor of social mobility in the migration literature, measurement of level of incorporation will be an important variable when considering the overall effects of educational pathway.

\subsection{Background Determinates to Social Mobility}

Portes and Rumbaut (2001) examined human capital, family structure, and modes of incorporation as key background determinants for generational paths of mobility. They argued that background determinants, together with socio-economic status and strength of co-ethnic community, differentiated mobility pathways for future generations. Within their model, education does play a role in one of the pathways; education only increases social mobility for the second generation of working class immigrants with strong co-ethnic communities. Despite including education in their model, however, Portes and Rumbaut (2001) do not differentiate between distinct educational pathways.

Portes, Fernández-Kelly, and Haller (2005) expanded on the background determinants introduced by Portes and Rumbaut (2001). The former looked at how education and job skills (human capital), two-parent household status, parental legal status, parental expectations and investment priorities (family situation), and different modes of incorporation influenced the social mobility of second-generation immigrants and found that those from advantaged backgrounds had higher social mobility. Zhou et al. (2008) built on Portes and Rumbaut (2001) and Portes, Fernández-Kelly, and Haller (2005) with findings that also generally correspond with what segmented assimilation theory would suggest; namely, that among those of relatively advantaged backgrounds, sustained upward mobility is as much the norm as a matter of class reproduction (Zhou et al., 2008, p. 59). Education does play a more prominent role in the model presented by Zhou et al. (2008), but education and occupational choices are seen as factors driven by background determinants and are treated as mostly homogenous in nature. In such a model, education appears to be a byproduct of background determinants, with other mechanisms being primary drivers of mobility. That is, education is treated as a homogenous factor through which background determinants operate to create class reproduction, rather than as a pathway that predicts or drives educational outcomes or social mobility in its own right. Feliciano and Lanuza (2017) recently reaffirmed the idea that class reproduction is key in determining social mobility by arguing that "contextual attainment" explains much of the immigrant advantage, and that children of immigrants are not experiencing the remarkable intergenerational mobility that scholars suggest (Farley \& Alba, 2002; Lee \& Zhou, 2013). Feliciano and Lanuza (2017) looked at parental years of schooling (and SES) but their models did not incorporate educational pathway.

\subsection{Education Literatures and Immigrants}

Much of the education literature surrounding immigrants has focused on institutional structure, including curricula and coursework (e.g., Lee \& Holland, 1993; Stevenson, Schiller, \& Schnieder, 1994), expectations and generalizations of teachers and administrators (Pallas et al., 1994), and access to resources and opportunities (Schnieder, Wyse, \& Keesler, 2006). Hao and Pong (2008) looked at the role of school in the mobility of immigrant children but focused on structural attributes of schools - specifically, high schools - as determining factors. While Hao and Pong's (2008) study looked at educational outcomes, the authors did not examine or address educational pathways in their analysis. The literature suggests, but has not explicitly examined, that educational pathway may mediate key background determinants identified by current literature. Current scholarship also suggests that educational pathway may impact educational outcomes and wages (Reynolds, 2012; Jehn, Walters, \& Howells, 2019). This dictates the need for analyses that help understand the drivers leading to educational pathway (contextual attainment), along with research intended to uncover the effect of educational pathway on educational outcomes and wages.

\section{Sample and Research Design}

The project research design is oriented across two distinct research components. The first research component 
looks to establishes predictive strengths of key variables on a student's chosen educational pathway. Using multinomial logit modeling, the results will help uncover the relationship of educational pathways with several key measurements, specifically GPA, a measure of the overall financial situation of the student's family, the perceived importance of good grades in school, the respondent's level of assimilation, race and gender. The second research component uses statistical analysis to understand the relationship between educational pathway, degree completion, and wages. More specifically, the analysis will create a predicted probability of degree completion by educational pathway and predicted relative wages by educational pathway.

The project uses data from the Children of Immigrants Longitudinal Study (CILS), housed in the Center for Migration and Development at Princeton University (additional information on the CILS dataset can be found in Appendix A). The sample includes data from 2796 respondents surveyed at three different periods over the course of a decade. Respondents were recruited from 49 different schools in Miami/Ft. Lauderdale, FL and San Diego, CA. Table 1 summarizes the key statistics of the sample.

Table 1. Description of sample

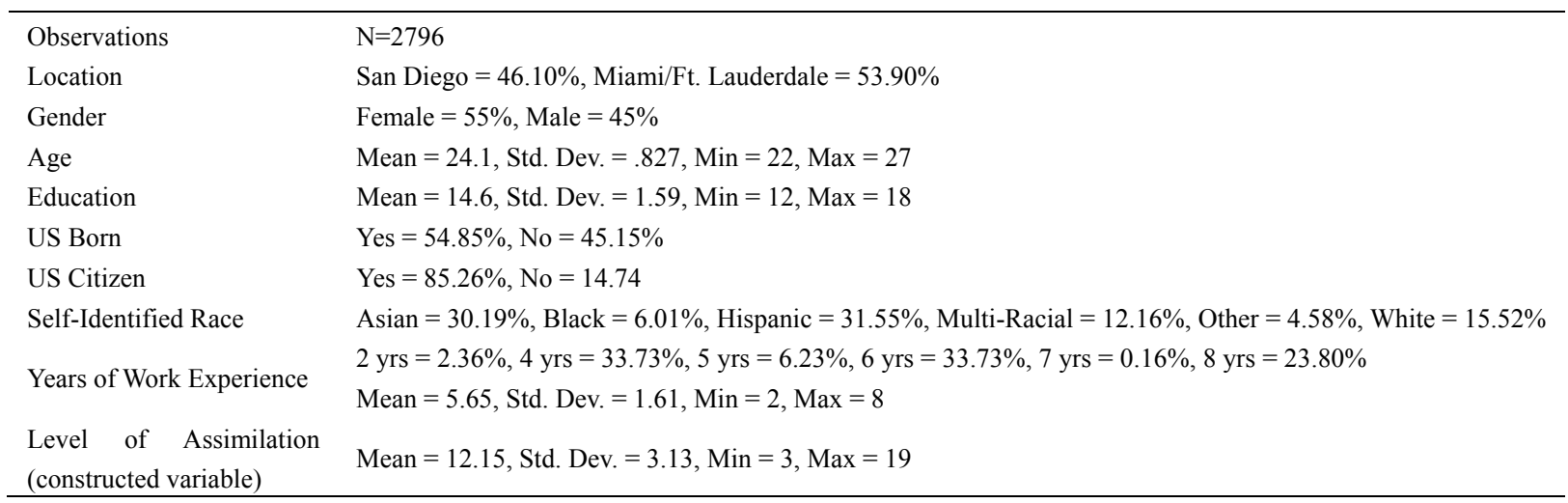

The key variable in this analysis is "educational pathway" which is defined as a student's original point of entry into the higher education system. This variable is constructed using several proxy measures found in the CILS dataset (A comprehensive description of variable constructions can be found in Appendix B). In this case, three pathways were identified: 1 - "No Higher Education," 2 - "Vocational/Community College," 3 - "Four-Year College." Table 2 illustrates the breakdown by educational pathway.

Table 2. Student by educational pathway

\begin{tabular}{ll}
\hline No Higher Education & 328 \\
Vocational/Community & 1,352 \\
Four-Year College & 1,116 \\
Total & 2,796 \\
\hline
\end{tabular}

\section{Findings}

\subsection{Educational Pathway as Dependent Variable: Multinomial Logit Modeling}

Before looking specifically at how educational pathway might affect degree completion or wages, it's important to understand the relationship of educational pathways with several key measurements, specifically GPA, a measure of the overall financial situation of the student's family (Note 1), the perceived importance of good grades in school, the respondent's level of assimilation (Note 2), race and gender. In total, five models were created and are presented in Table 3. 
Table 3. Multinomial logit modeling of educational pathways

\begin{tabular}{|c|c|c|c|c|c|c|c|c|c|c|c|c|c|c|c|}
\hline & & Model & & & Model 2 & & & Model 3 & & & Model 4 & & & Model 5 & \\
\hline \multirow{2}{*}{ VARIABLES } & No Higher & Vocational/ & Four-Year College & No Higher & Vocational/ & & No Higher & Vocational/ & Four-Year & No Higher & Vocational/ & Four-Year & No Higher & Vocational/ & Four-Year \\
\hline & Education & Community & & Education & Community & College & Education & Community & College & Education & Community & College & Education & Community & College \\
\hline \multirow{2}{*}{ GPA } & $-0.466 * * *$ & & $1.350^{* * *}$ & $-0.490 * * *$ & & $1.341^{* * *}$ & $-0.490^{* * *}$ & & $1.329 * * *$ & $-0.472^{* * *}$ & & $1.355^{* * *}$ & $-0.449 * * *$ & & $1.309 * * *$ \\
\hline & $(0.0785)$ & & $(0.0638)$ & $(0.0802)$ & & $(0.0649)$ & $(0.0805)$ & & $(0.0653)$ & $(0.0882)$ & & $(0.0706)$ & $(0.0932)$ & & $(0.0734)$ \\
\hline \multirow{2}{*}{ SES } & & & & $-0.666^{* * *}$ & & $0.503 * * *$ & $-0.663 * * *$ & & $0.501 * * *$ & $-0.609^{* * *}$ & & $0.465^{* * *}$ & $-0.613^{* * *}$ & & $0.450^{* * *}$ \\
\hline & & & & $(0.0896)$ & & $(0.0648)$ & $(0.0899)$ & & $(0.0650)$ & $(0.102)$ & & $(0.0727)$ & $(0.105)$ & & $(0.0741)$ \\
\hline \multirow{2}{*}{ Grades Important? } & & & & & & & -0.0686 & & 0.190 & -0.102 & & 0.175 & -0.0956 & & 0.161 \\
\hline & & & & & & & $(0.148)$ & & $(0.118)$ & $(0.162)$ & & $(0.126)$ & $(0.163)$ & & $(0.127)$ \\
\hline Assimilation & & & & & & & & & & $-0.0638^{* * *}$ & & 0.00880 & $-0.0731 * * *$ & & 0.00120 \\
\hline \multirow{2}{*}{ 2.race (Black) } & & & & & & & & & & $(0.0235)$ & & $(0.0163)$ & $(0.0243)$ & & $(0.0169)$ \\
\hline & & & & & & & & & & & & & -0.226 & & -0.117 \\
\hline \multirow{2}{*}{ 3.race (Asian) } & & & & & & & & & & & & & $(0.357)$ & & $(0.252)$ \\
\hline & & & & & & & & & & & & & 0.0131 & & $0.349 * *$ \\
\hline \multirow{2}{*}{ 4.race (Hispanic) } & & & & & & & & & & & & & $(0.251)$ & & $(0.158)$ \\
\hline & & & & & & & & & & & & & 0.123 & & $-0.268^{*}$ \\
\hline \multirow{2}{*}{ 5.race (Multi-racial) } & & & & & & & & & & & & & $(0.213)$ & & $(0.159)$ \\
\hline & & & & & & & & & & & & & 0.180 & & -0.0223 \\
\hline \multirow{2}{*}{ 6.race (Other) } & & & & & & & & & & & & & $(0.272)$ & & $(0.189)$ \\
\hline & & & & & & & & & & & & & -0.380 & & 0.0205 \\
\hline \multirow{3}{*}{ Gender } & & & & & & & & & & & & & $(0.395)$ & & $(0.273)$ \\
\hline & & & & & & & & & & & & & -0.215 & & $-0.248^{* *}$ \\
\hline & & & & & & & & & & & & & $(0.148)$ & & $(0.105)$ \\
\hline \multirow{3}{*}{ Constant } & $-0.368^{* *}$ & & $-4.016 * * *$ & $-0.444 * *$ & & $-4.044 * * *$ & $-0.387 *$ & & $-4.163 * * *$ & 0.277 & & $-4.336 * * *$ & 0.396 & & $-3.979 * * *$ \\
\hline & $(0.181)$ & & $(0.189)$ & $(0.186)$ & & $(0.193)$ & $(0.211)$ & & $(0.209)$ & $(0.365)$ & & $(0.301)$ & $(0.415)$ & & $(0.333)$ \\
\hline & & $(0.181)$ & $(0.242)$ & & $(0.186)$ & $(0.249)$ & & $(0.211)$ & $(0.275)$ & & $(0.365)$ & $(0.435)$ & & $(0.415)$ & $(0.487)$ \\
\hline Observations & 2,757 & 2,757 & 2,757 & 2,757 & 2,757 & 2,757 & 2,742 & 2,742 & 2,742 & 2,388 & 2,388 & 2,388 & 2,388 & 2,388 & 2,388 \\
\hline
\end{tabular}

Note. Standard errors in parentheses; $* * * \mathrm{p}<0.001,{ }^{* *} \mathrm{p}<0.01,{ }^{*} \mathrm{p}<0.05$; Constructed using a unit-weighted standardized scale of father's and mother's education, and occupational SEI scores, plus family home ownership; Measured using the variable "assimilation index" that was constructed using several variables within dataset.

Resulted showed several important findings. First, GPA and SES remain statistically significant across all pathways, supporting the established notion that children of immigrants who come from relatively advantaged backgrounds have a higher likelihood of educational attainment (e.g. Zhou et al., 2008). The model also shows that gender is negatively correlated with the four-year college pathway suggesting that female children of immigrants are less likely to enter through the four-year pathway than their males counterparts (Note 3). Finally the model shows some variation in race, specifically, the Asian category has a higher likelihood of entering the higher education system directly into four year institutions.

\subsection{Educational Pathway and Its Effect on Bachelor's Degree Completion}

Next a set of models were created to show the relationship between educational pathway and degree completion. Findings show that student's had a significantly lower likelihood of completing a bachelor's degree when entering though the community college pathway (see Table 4). The predicted probability of degree completion through the vocational/educational pathway is 13.99 percent, and 51.75 percent for the four-year college pathway (controlling for GPA, SES, importance of grades, and level of assimilation). Overall (controlling for pathway), the predicted probability of degree completion is 33.43 percent. 
Table 4. Logit regression on degree completion (ba)

\begin{tabular}{|c|c|c|}
\hline & Model 1 & Model 2 \\
\hline VARIABLES & $\mathrm{Ba}$ & ba \\
\hline \multirow{2}{*}{ 2.Vocational/Community College Pathway } & & $-2.413 * * *$ \\
\hline & & $(0.138)$ \\
\hline \multirow{2}{*}{ 3.Four-Year College Pathway (Omitted) } & & 0 \\
\hline & & $(0)$ \\
\hline \multirow{2}{*}{ Socioeconomic Status } & $0.789 * * *$ & $0.613 * * *$ \\
\hline & $(0.082)$ & $(0.091)$ \\
\hline \multirow{2}{*}{ Grade Point Average } & $1.590 * * *$ & $1.129 * * *$ \\
\hline & $(0.083)$ & $(0.093)$ \\
\hline \multirow{2}{*}{ Are Grades Important? } & 0.154 & 0.0379 \\
\hline & $(0.138)$ & $(0.158)$ \\
\hline \multirow{2}{*}{ Level of Assimilation } & $0.0398 * *$ & 0.0331 \\
\hline & $(0.018)$ & $(0.020)$ \\
\hline \multirow{2}{*}{ 2.race (Black) } & 0.158 & 0.269 \\
\hline & $(0.263)$ & $(0.309)$ \\
\hline \multirow{2}{*}{ 3.race (Asian) } & $-0.628 * * *$ & $-1.071 * * *$ \\
\hline & $(0.168)$ & $(0.198)$ \\
\hline \multirow{2}{*}{ 4.race (Hispanic) } & -0.218 & -0.136 \\
\hline & $(0.168)$ & $(0.197)$ \\
\hline \multirow{2}{*}{ 5.race (Multi-racial) } & $-0.548 * * *$ & $-0.743 * * *$ \\
\hline & $(0.204)$ & $(0.239)$ \\
\hline \multirow{2}{*}{ 6.race (Other) } & -0.317 & -0.411 \\
\hline & $(0.308)$ & $(0.348)$ \\
\hline \multirow{2}{*}{ Constant } & $-5.887 * * *$ & $-3.033 * * *$ \\
\hline & $(0.372)$ & $(0.421)$ \\
\hline Observations & 2,388 & 2,127 \\
\hline
\end{tabular}

Note. Standard errors in parentheses; ${ }^{* * *} \mathrm{p}<0.001,{ }^{* *} \mathrm{p}<0.01,{ }^{*} \mathrm{p}<0.05$.

Table 5 represents predicted probabilities of degree completion by race and pathway. Asians in both pathways have a lower predicted probability of degree completion than students of any other race category. Considering the substantially higher predicted probability of degree completion for those in the four-year college pathway and the statistically significant positive relationship between the Asian category and the four-year college pathway, the result is counterintuitive especially since research exploring educational attainment and race has shown that Asian children of immigrants tend to excel (Kasinitz et al., 2007).

Table 5. Predicted probability of degree completion by race

\begin{tabular}{lccc}
\hline & Overall-Controlling for Pathway & Vocational/Community College Pathway & Four-Year College Pathway \\
\hline White & $39.88 \%$ & $25.02 \%$ & $52.31 \%$ \\
Black & $43.29 \%$ & $27.40 \%$ & $55.11 \%$ \\
Asian & $26.89 \%$ & $16.82 \%$ & $41.08 \%$ \\
Hispanic & $38.16 \%$ & $21.94 \%$ & $48.41 \%$ \\
Multi-racial & $30.74 \%$ & $17.60 \%$ & $42.51 \%$ \\
Other & $34.77 \%$ & $20.62 \%$ & $46.63 \%$ \\
\hline
\end{tabular}

\subsection{Educational Pathway and Wages}

The data also show differences in wages between educational pathways. Table 6 summarizes the mean wage of respondents by pathway and degree completion. One might expect that across educational pathways, wages would be similar for respondents with identical educational outcomes, but the data show different results. Among respondents who completed a bachelor's degree or higher, those who entered through the four-year college pathway directly are earning about 25 percent more, on average, than those who entered through the 
vocational/community college pathway first and then transferred to a four-year institution. This reveals a definitive pathway wage penalty among those who completed their degree; even when a BA is completed, students who first entered the system through the vocational/community college pathway earn less. Interestingly, among students who did not complete a bachelor's degree or higher, those who entered through the community college pathway are seeing higher wages than students who entered directly to a four-year institution but failed to obtain their degree.

Table 6 . Mean wages by educational pathway

\begin{tabular}{lccc}
\hline & \multicolumn{3}{c}{ Bachelor's Degree } \\
\cline { 2 - 4 } & No & Yes & Total \\
\hline No Higher Education & $\$ 1,884.22$ & $\$-$ & $\$ 1,884.22$ \\
Vocational/Community & $\$ 2,204.89$ & $\$ 1,922.55$ & $\$ 2,177.66$ \\
Four-Year College & $\$ 2,023.62$ & $\$ 2,416.53$ & $\$ 2,355.26$ \\
Total & $\$ 2,069.66$ & $\$ 2,367.01$ & $\$ 2,177.81$ \\
\hline
\end{tabular}

Note. Data only include respondents not enrolled in school at the time of the third wave.

Lastly, four models were created to uncover the relationship between educational pathway and wages. Results can be found in Table 7. Model 1 and 2 regressed degree completion and educational pathway separately on wages and both show to be statistically significant. The models show that respondents in the vocational/community college pathway are predicted to earn 14.4 percent more than those with no higher education. Respondents in the four-year college pathway are predicted to earn 18.5 percent more than those with no higher education. So, comparatively, the regression confirms that a pathway wage penalty does exist. Interestingly, however, when degree completion and educational pathway are combined in the same model (Model 3), only educational pathway remains significant.

Table 7. Regression on wages

\begin{tabular}{lcccc}
\hline & $\begin{array}{c}\text { Model 1: } \\
\text { regression of ba on } \\
\text { lnwage }\end{array}$ & $\begin{array}{c}\text { Model 2: } \\
\text { regression of pathway } \\
\text { on lnwage }\end{array}$ & $\begin{array}{c}\text { Model 3: } \\
\text { regression of ba and } \\
\text { pathway on lnwage }\end{array}$ & $\begin{array}{c}\text { Model 4: } \\
\text { regression of ba and } \\
\text { pathway on lnwage - FT } \\
\text { workers only }\end{array}$ \\
\hline Variable & $\begin{array}{c}\text { lnwage } \\
\text { ba }\end{array}$ & lnwage & lnwage & lnwage \\
2.115*** & $(0.0371)$ & & 0.0795 & 0.0851 \\
3ocational/Community Pathway & & $0.144^{* * *}$ & $(0.0615)$ & $(0.0575)$ \\
3. Four-Year College Pathway & & $(0.0469)$ & $(0.0472)$ & $0.144^{* * *}$ \\
Constant & & $0.185^{* * *}$ & $0.118^{*}$ & $(0.0435)$ \\
Observations & $(0.0466)$ & $(0.0698)$ & $0.178^{* * *}$ \\
R-squared & $(-0.0224)$ & $(0.0368)$ & $7.395^{* * *}$ & $(0.0652)$ \\
\hline Note. Stant* & 1,042 & $(0.0368)$ & $7.458^{* * *}$ \\
$(1,042$ & 0.016 & 1,042 & $8.034)$ \\
\hline
\end{tabular}

Note. Standard errors in parentheses; ${ }^{* * *} \mathrm{p}<0.001,{ }^{* *} \mathrm{p}<0.01,{ }^{*} \mathrm{p}<0.05$.

\section{Discussion}

As evident with the results, educational pathway certainly affects both degree completion and wages. While the four-year college pathway showed a clear advantage for those hoping to complete a bachelor's degree or above, the results for wages yielded some unexpected findings. First, respondents who completed their degree, a pathway wage penalty was clearly evident for respondents in the vocational/community college pathway. Despite both sets of respondents having college degrees, those who entered through the four-year college pathway are earning, on average, 21 percent more than students in the vocational/community college pathway. Next, Looking at students who did not finish their degree, students in the vocational/community college pathway earned an average of 9 percent more than those in the four-year college pathway. In fact, these findings might underestimate the true 
long-term effect for those students who entered through the four-year college pathway but did not finish their degree. Considering the probable differences in tuition between a four-year college and a vocational/community college, the overall financial situation could be much worse than just the small difference in mean wages. Furthermore, given the vocational nature of some community colleges' curricula and the academic nature of four-year college curricula, the potential long-term financial trajectory of the respondents who do not ultimately complete a degree might be more limited for those in the four-year college pathway. Identifying which degrees students graduated with and then comparing students with identical degree majors by pathway would allow for a more definitive conclusion about the degree to which a pathway wage penalty exists for students who do not attain a bachelor's degree or higher. Understanding the nature of the schoolwork done by students who didn't complete their degree — including any certificates or certifications earned before exit from school—would also allow for a more definitive conclusion about the varying longer-term trajectories for students from different educational pathways who did not complete their degrees.

The findings show a substantial difference in the likelihood of degree completion between educational pathways for children of immigrants. The probability of completing a bachelor's degree was about 13 percent for those entering through the vocational/community college pathway and 52 percent for those entering through the four-year college pathway. The analysis on wages shows a substantial pathway wage penalty for students in the vocational/community college pathway that did complete their degrees, while the pathway wage penalty disappeared for the students who did not finish their degrees. These findings suggest the need for further exploration into the effect of vocational training on wages, as well as a need to understand why such a significant pathway wage penalty exists for degree holders. Do employers reward applicants with the preferred pathway —net of merit or credentials? Is it possible that perceived "quality of degree" (partially driven by pathway, presumably) is the driving factor? For those without degrees, is the driving factor the vocational credentials and certifications earned (mostly driven by pathway_again, presumably)?

Analysis is also needed to understand if the pathway wage penalty still exists once type and subject of degree are controlled for. As mentioned above, identifying which degrees students have obtained and comparing same-major graduates between pathways would allow for a more definitive conclusion about the extent to which a pathway wage penalty exists.

\section{Conclusion}

Findings from this research show that educational pathway mediates many of the background determinants that the migration literature identifies as key mechanisms for social mobility. Scholarship to date has focused on intergenerational outcomes driven by background determinants and education has been treated as a homogenous byproduct of background determinants presumed to be primarily responsible for class reproduction. However, this paper shows that educational pathway is an important mechanism driving degree completion and wages in its own right.

Furthermore, it is important for research on the nexus between migration and education to include and give special attention to community colleges because immigrant students attend community colleges more often than any other type of postsecondary institution (C. Suárez-Orozco, M. Suárez-Orozco, \& Todorova, 2008). Previous migration research has focused on educational attainment without delineating educational pathways. This paper expands the broader immigrant scholarship by differentiating between educational pathways, and specifically examining vocational/community colleges within the context of the higher education system, in order to understand each pathway's unique impact on degree completion and wages. Results suggest that administrators and policy makers should have an increased focus degree completion for community colleges given the stark differences in predicted completion in the sample.

Immigrants and their children represent one-sixth of the current U.S. population. New immigration, plus births to immigrants, added more than 22 million people to the U.S. population in the last decade, equal to 80 percent of the country's total population growth. Immigrants and their children now account for more than one in five public school students. This dramatic demographic shift underscores the importance of research examining the experience of immigrants. The high stakes involved in drawing accurate conclusions about immigrants' social mobility in the context of our higher education system - given the competitiveness of contemporary economic conditions; the changing demands for the work force; and the growing percentage of children of immigrants reaching adulthood - cannot be overstated. This paper offers an opportunity to deepen our understanding of how the current structure of our higher education system differentiates outcomes based on educational pathways.

\section{References}

Alba, R., \& Nee, V. (1997). Rethinking assimilation theory for a new era of immigration. International migration 
review, 31(4), 826-874. https://doi.org/10.1177/019791839703100403

Breen, R. (2019). Education and intergenerational social mobility in the US and four European countries. Oxford Review of Economic Policy, 35(3), 445-466, https://doi.org/10.1093/oxrep/grz013

Buriel, R. (2012). Historical origins of the immigrant paradox for Mexican American students: The cultural integration hypothesis. In C. Garcia-Coll, \& A. K. Marks (Eds.), The immigrant paradox in children and adolescents: Is becoming American a developmental risk? (pp. 37-60). Washington, DC: American Psychological Association. https://doi.org/10.1037/13094-002

Farley, R., \& Alba, R. (2002). The new second generation in the United States. International migration review, 36(3), 669-701. https://doi.org/10.1111/j.1747-7379.2002.tb00100.x

Feliciano, C., \& Lanuza, Y. R. (2016). The immigrant advantage in adolescent educational expectations. International Migration Review, 50(3), 758-792. https://doi.org/10.1177/0003122416684777

Feliciano, C., \& Lanuza, Y. R. (2017). An immigrant paradox? Contextual attainment and intergenerational educational mobility. American Sociological Review, 82(1), 211-241. https://doi.org/10.1111/imre.12183

Goyette, K., \& Xie, Y. (1999). Educational expectations of Asian American youths: Determinants and ethnic differences. Sociology of Education, 72(1), 22-36. https://doi.org/10.2307/2673184

Hao, L., \& Bonstead-Bruns, M. (1998). Parent-child differences in educational expectations and the academic achievement of immigrant and native students. Sociology of Education, 71(3), 175-198. https://doi.org/10.2307/2673201

Hao, L., \& Pong, S. L. (2008). The role of school in the upward mobility of disadvantaged immigrants' children. The ANNALS of the American Academy of Political and Social Science, 620(1), 62-89. https://doi.org/10.1177/0002716208322582

Hao, L., \& Woo, H. S. (2012). Distinct trajectories in the transition to adulthood: Are children of immigrants advantaged? Child Development, 83(5), 1623-1639. https://doi.org/10.1111/j.1467-8624.2012.01798.x

Haveman, R., \& Smeeding, T. (2006). The Role of Higher Education in Social Mobility. The Future of Children, 16(2), 125-150. https://doi.org/10.1353/foc.2006.0015

Hsin, A., \& Xie, Y. (2014). Explaining Asian Americans' academic advantage over whites. Proceedings of the National Academy of Sciences, 111(23), 8416-8421. https://doi.org/10.1073/pnas.1406402111

Jehn, A., Walters, D., \& Howells, S. (2019). Employment and Wage Gaps Among Recent Canadian Male and Female Postsecondary Graduates. Higher Education Policy, 1-23. https://doi.org/10.1057/s41307-019-00162-0

Kao, G., \& Tienda, M. (1995). Optimism and achievement: The educational performance of immigrant youth. Social science quarterly, 76(1), 1-19.

Kasinitz, P., Mollenkopf, J. H., Waters, M. C., \& Holdaway, J. (2007). Inheriting the city: The children of immigrants come of age. Russell Sage Foundation.

Lee, J., \& Zhou, M. (2013). Frames of achievement and opportunity horizons. Immigration, poverty, and socioeconomic inequality, 206-231.

Lee, V. E., \& Holland, P. B. (1993). Catholic schools and the common good. Harvard University Press. https://doi.org/10.2307/j.ctvjz82r6.16

Pallas, A. M., Entwisle, D. R., Alexander, K. L., \& Stluka, M. F. (1994). Ability-group effects: Instructional, social, or institutional? Sociology of education, 67(1), 27-46. https://doi.org/10.2307/2112748

Pong, S. L., \& Hao, L. (2007). Neighborhood and school factors in the school performance of immigrants' children. International Migration Review, 41(1), 206-241. https://doi.org/10.1111/j.1747-7379.2007.00062.x

Portes, A, \& Rumbaut, R. G. (2001). Legacies: The Story of the Immigrant Second Generation. University of California Press and Russell Sage Foundation.

Portes, A., \& Zhou, M. (1993). The new second generation: Segmented assimilation and its variants. The annals of the American academy of political and social science, 530(1), 74-96. https://doi.org/10.1177/0002716293530001006

Portes, A., Fernandez-Kelly, P., \& Haller, W. (2005). Segmented assimilation on the ground: The new second generation in early adulthood. Ethnic and racial studies, 28(6), 1000-1040. 
https://doi.org/10.1080/01419870500224117

Reitz, J. G. (2018). Warmth of the welcome: The social causes of economic success in different nations and cities. Routledge.

Reynolds, C. L. (2012). Where to attend? Estimating the effects of beginning college at a two-year institution. Economics of Education review, 31(4), 345-362. https://doi.org/10.1016/j.econedurev.2011.12.001

Schneider, B., Wyse, A. E., \& Keesler, V. (2006). Is small really better? Testing some assumptions about high school size. Brookings papers on education policy, (9), 15-47. https://doi.org/10.1353/pep.2007.0008

Smith, J. P. (2003). Assimilation across the Latino generations. American Economic Review, 93(2), 315-319. https://doi.org/10.1257/000282803321947263

Solon, G. (2018). What Do We Know So Far about Multigenerational Mobility? The Economic Journal, 128(612), F340-F352, https://doi.org/10.1111/ecoj.12495

Stevenson, D. L., Schiller, K. S., \& Schneider, B. (1994). Sequences of opportunities for learning. Sociology of Education, 67(3), 184-198. https://doi.org/10.2307/2112790

Suárez-Orozco, C., Suárez-Orozco, M. M., \& Todorova, I. (2008). Learning a new land. Harvard University Press.

Torche, F. (2011). Is a college degree still the great equalizer? Intergenerational mobility across levels of schooling in the United States. American Journal of Sociology, 117(3), 763-807. https://doi.org/10.1086/661904

Tran, V. C. (2018). Social Mobility across Immigrant Generations: Recent Evidence and Future Data Requirements. The ANNALS of the American Academy of Political and Social Science, 677(1), 105-118. https://doi.org/10.1177/0002716218762725

Zhou, M., \& Bankston, C. (1998). Growing up American: How Vietnamese children adapt to life in the United States. Russell Sage Foundation.

Zhou, M., Lee, J., Vallejo, J. A., Tafoya-Estrada, R., \& Sao-Xiong, Y. (2008). Success attained, deterred, and denied: Divergent pathways to social mobility in Los Angeles's new second generation. The ANNALS of the American Academy of Political and Social Science, 620(1), 37-61. https://doi.org/10.1177/0002716208322586

\section{Appendix A}

The study followed children of immigrants beginning in 1992, while they were still enrolled in secondary school $\left(8^{\text {th }} / 9^{\text {th }}\right.$ grade). A follow-up survey was done in 1995 , prior to graduation, and a final survey was conducted in 2002. To be eligible to participate, the student needed to have at least one foreign-born biological parent and either had to have been born in the United States or to have resided in the United States for at least five years leading up to the study. Students were recruited from 49 different schools in Miami/Ft. Lauderdale, FL and San Diego, CA. The sample was evenly divided by sex and year in school, and approximately 54 percent of the sample was drawn from Miami/Ft. Lauderdale. The first survey captured information about the immigrant families, along with the children's demographic characteristics; children's language use and mastery; and children's academic goals, expectations, and attainment. The first survey consisted of 5,267 students. The second survey, conducted three years later, was purposely timed to survey students as they were preparing to finish high school and potentially entering into the higher education system; the second wave also followed up with the students who had dropped out of school in the time period between the initial survey and follow-up. At this time, the study also interviewed parents, in the hopes of understanding their outlook on their children's future, including parents' expectations and plans for them. The second wave successfully surveyed 4,288 students representing about 81 percent of the original sample, in addition to the 2,446 parents who were successfully interviewed. The third and final survey was conducted a decade after the first. The average age of the first-wave students, by this time, was 24 years, and the survey used a combination of mailed questionnaires, and telephone and in-person interviews. In total, the third survey succeeded in reaching 84 percent of the second survey sample and about 70 percent of the original sample. 


\section{Appendix B}

\section{Constructed Variables}

Educational Pathway - Since my primary interest lies in educational pathways, I am limiting the data to those respondents who were interviewed in all three waves and expressed interest in entering the higher education system in the second wave (Note 4, Note 5). As indicated above, respondents who were successfully reached in the third wave had finished high school 5-7 years prior and would have had the ability to enter the higher education system by then.

Educational pathway was constructed using data from several variables. First, I took each respondent's highest degree or level of school reached (question v407) and coded those who indicated high school graduation only as having "no higher education." I coded those who indicated one-to-two years of community college or a two-year associate's degree as having attended "vocational/community college." Finally, those who indicated some college ( $3+$ years), graduation from a four-year college, some graduate school, a master's degree, and/or a professional or doctoral degree were coded as "four-year college."

Understanding that it is possible that some students who indicated $3+$ years of college or higher had entered first through vocational or community college, my next step was to make sure these students were correctly coded into the appropriate pathway. Using the question that asked whether an associate's degree had been obtained, I recoded respondents thus: if a student originally coded as "four-year college" had indicated that he or she had completed an associate's degree, I moved them from "four-year college" to "vocational/community college" to describe their educational pathway more accurately.

Lastly, I looked at respondents who were currently enrolled in school at the time of the third wave (question v409a) to ensure that they were correctly coded in the appropriate pathway. I found that a small number of respondents who had marked high school graduation as their highest level of school completed, and thus initially in the "no higher education" pathway, were currently enrolled in the higher education system in some capacity. I recoded each of those respondents into the pathway reflecting his or her respective, current enrollment.

Assimilation - The variable used to measure level of assimilation is a constructed variable drawing upon several measures within the dataset. The following questions were recoded and the recoded scores were combined to produce the variable "assimilation index":

"Language other than English used at home?" - Question v55

Recoded to $0=$ yes, $1=$ no

"Is respondent registered to vote?" - Question v442

$0=$ no, $1=$ yes

"Which feels more like 'home"”? - Question v447

Recoded to $0=$ all other countries, $1=$ United States

"Does American way of life weaken family?" - Question v280

Recoded to $0=$ yes, $1=$ no

Do you agree with the following statement - "No better place than US?" - Question v283

Recoded to $0=$ no, $1=$ yes

"How often respondent prefers American ways" - Question v98

Recoded to 0 = "sometimes" or "never," 1 = "most of the time" or "all of the time"

"Length of time respondent has lived in US" - Question v222

Recoded $0=$ less than 10 years, $1=10+$ years

The mean score for the assimilation index variable is 5.005 with a standard deviation of 1.227 , a minimum score of 
0 , and a maximum score of 7 .

Ambition - In an attempt to understand if student ambition plays a role in determining educational pathways, I will use the answers to the question that asked, "How important is getting good grades in school to you?" in the model as a proxy for student ambition. This is a dichotomous variable and 79.14 percent of respondents indicated that grades were important to them.

\section{Notes}

Note 1. Measured using the variable "socioeconomic status index" that was constructed using a unit-weighted standardized scale of father's and mother's education and occupational SEI scores, plus family home ownership. Scores were computed for all cases with valid measures in three or more of the component variables.

Note 2. Measured using the variable "assimilation index," which was constructed using several variables within the dataset. See Appendix B for details.

Note 3. Gender variable coded male $=0$, females $=1$

Note 4 . The second survey was purposely timed to survey students as they were preparing to finish high school and potentially enter the higher education system.

Note 5. I will use responses from question "v260 - What is the highest level of education that you would like to achieve?" to remove respondents indicating no interest in entering the higher education system. This only represents 3.85 percent of the respondents who completed all waves.

\section{Copyrights}

Copyright for this article is retained by the author(s), with first publication rights granted to the journal.

This is an open-access article distributed under the terms and conditions of the Creative Commons Attribution license (http://creativecommons.org/licenses/by/4.0/). 